\title{
Clusters of shallow pits in gastropod shells from the type area of the Maastrichtian (Upper Cretaceous, the Netherlands)
}

\author{
Stephen K. Donovan, John W.M. Jagt \& Paul H.M. van Knippenberg
}

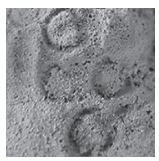

\begin{abstract}
Close-set, shallow pits are preserved in external moulds of one species each of campanilid and aporrhaid gastropods from coquinas in the uppermost Maastrichtian Meerssen Member (subunit IVf-6) at the former Ankerpoort-Curfs quarry (Geulhem, southern Limburg, the Netherlands). These clustered pits are broad, dish-like, and rounded to polygonal where closely packed; a circular, sunken groove lies within the dish; and a central rounded dome has a central, rounded depression. The producing organism obviously pursued a gregarious lifestyle. These structures are referred to a new ichnotaxon, Salsariichnus collinsi igen. et isp. nov., which is considered to belong to the ethological class of domichnia. It differs in several respects from attachment scars (ichnogenus Lacrimichnus) and deeper embedment structures such as Oichnus excavatus that are known from coeval levels. - Key words: Maastricht Formation, Meerssen Member, Salsariichnus, domichnia.
\end{abstract}

Donovan, S.K., Jagt, J.W.M. \& Van KnippenberG, P.H.M. 2019. Clusters of shallow pits in gastropod shells from the Maastrichtian type area (Upper Cretaceous, the Netherlands). Bulletin of Geosciences 94(4), 425-430 (3 figures). Czech Geological Survey, Prague. ISSN 1214-1119. Manuscript received June 13, 2019; accepted in revised form October 10, 2019; published online December 10, 2019; issued December 31, 2019.

Stephen K. Donovan, Taxonomy \& Systematics Group, Naturalis Biodiversity Center, Postbus 9517, 2300 RA Leiden, the Netherlands; Steve.Donovan@naturalis.nl•John W.M. Jagt, Natuurhistorisch Museum Maastricht, de Bosquetplein 6-7, 6211 KJ Maastricht, the Netherlands • Paul H.M. van Knippenberg, Gelrestraat 10, 5995 XH Kessel, the Netherlands

Gastropods and, particularly, their shells are amongst the wonders of the natural world, but perhaps they are so familiar as to be rather taken for granted. Most pertinent to the present study is the fact that gastropod shells may be used as hard substrates for encrusting and boring organisms to inhabit or foul. In life, the external surfaces of gastropod shells of (particularly) marine snails may be host to a wide variety of episkeletozoans (sensu Taylor \& Wilson 2002). An empty snail shell in a marine setting is a valuable substrate; a genuine benthic island (compare with Tapanila \& Ebbestad 2008, Belaústegui et al. 2013), being available for attachment and invasion both internally and externally (Pickerill \& Donovan 1997). Indeed, empty conchs may be of such value that even extinct species are recycled and utilised by extant hermit crabs (Gould 1980).

Herein, we examine trace fossils associated with natural external moulds (the internal moulds were not found in association) of three medium- to large-sized gastropod shells from the type area of the Maastrichtian Stage (Upper Cretaceous). These shells provided substrates for infestation after death; each of them has been densely infested by unknown organisms that left behind close-packed, shallow, discoidal pits. These cannot be ascribed to Oichnus Bromley, 1981, already well known from all members of the Maastricht Formation and often densely infesting their benthic islands, commonly the holasteroid echinoid Hemipneustes striatoradiatus Leske, 1778 (see, for example, Donovan \& Jagt 2002, 2013, in press; Donovan et al. 2018) or ostreid bivalves (Jagt \& Deckers 2014). Rather, they are interpreted as a morphologically distinct, new ichnogenus of domicile trace fossils (ethological class: domichnia). All specimens are deposited in the collections of the Natuurhistorisch Museum Maastricht, the Netherlands (prefix NHMM PK).

\section{Locality and horizon}

The present examples, NHMM PK M2643-1, PK M3083 and MK M3094, all originate from the former AnkerpoortCurfs quarry [outcrop 62A-13, coordinates 182.000/320.120; now a nature reserve of Stichting 'Het Limburgs Landschap'], near Geulhem, southern Limburg, the Netherlands (Fig. 1; for a more detailed map, see Felder \& Bosch 2000, fig. 3.49). At this locality, the uppermost metre or so of the Nekum Member and the entire Meerssen Member 


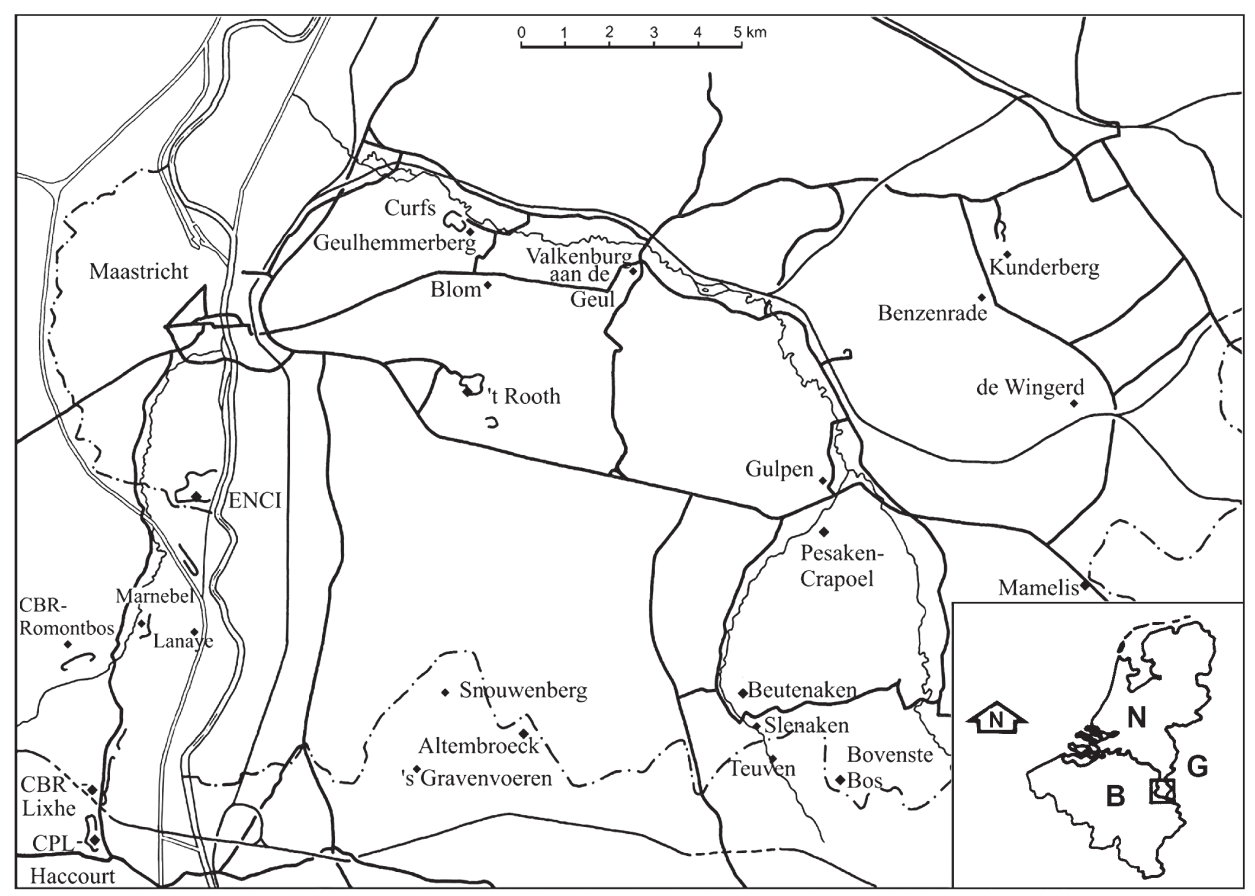

Figure 1. Map of southern Limburg, the Netherlands, and contiguous areas in northeast Belgium (Voerstreek, provinces of Limburg and Liège) and western Germany (Aachen area), showing the most important localities [(temporary) outcrops and quarries] in the type area of the Maastrichtian Stage (after Jagt \& Jagt-Yazykova 2012, fig. 1). The position of the former Ankerpoort-Curfs quarry, which yielded the specimens described herein, is in the upper part of the map and left of centre. The inset map of northern Europe $(\mathrm{B}=\mathrm{Bel}-$ gium; $\mathrm{G}=$ Germany; $\mathrm{N}=$ Netherlands) shows the position of the main map (box).

(subunits IVf-1 to IV-7) of the Maastricht Formation (upper Maastrichtian), as well as the overlying lower Palaeocene Geulhem Member (Houthem Formation), were formerly exposed (Herngreen \& Wong 2007, p. 142, fig. 18; Jagt \& Jagt-Yazykova 2012, fig. 5, tab. 1; Jagt et al. 2013, fig. 2a). The upper $20 \mathrm{~cm}$ or so of subunit IVf- 6 comprised laterally discontinuous coquinas or lumachelles from which molluscan material was collected already in the second half of the nineteenth century (Binkhorst van den Binkhorst 1861-1862, Ubaghs 1879, Kaunhowen 1898). These shell beds have yielded hundreds of close-packed specimens (predominantly internal and external moulds, except for ostreids and neritids) of gastropods, bivalves, scaphopods, nautiloids and ammonites, in association with scleractinian corals, echinoids, and rare decapod crustaceans and belemnitellid coleoids. On cephalopod evidence, the upper part (subunits IVf-4 to -6) of Meerssen Member can be dated as latest Maastrichtian, within the zones of the belemnitellid species, Belemnella (Neobelemnella) kazimiroviensis (Skołozdrówna, 1932) and B. (N.) skolozdrownae Kongiel, 1962 (see Keutgen et al. 2017), and the final one million years of the Cretaceous (Keutgen 2018, fig. 4).

\section{Systematic ichnology}

\section{Ichnogenus Salsariichnus nov.}

Type species. - Salsariichnus collinsi igen. nov., isp. nov., the only ichnospecies known.
Etymology. - From the Latin salsarium, saucer (Brown 1993, p. 2693).

Diagnosis. - Clustered shallow pits; gregarious; pits broad, dish-like, rounded to polygonal where closely packed; circular, sunken groove within dish; central rounded dome with a central, rounded depression.

Remarks. - Other rounded 'scars' have been recorded from the type Maastrichtian in recent years, but these all differ from Salsariichnus collinsi igen. nov., isp. nov. Best known is Oichnus excavatus Donovan \& Jagt, 2002; these are non-penetrative, gently undercut pits with a central boss, much deeper than the new trace described herein. Although $O$. excavatus is confined to holasteroid echinoid substrates in the upper Maastrichtian of the study area, it has been recorded from a Miocene gastropod of Jamaica (Blissett \& Pickerill 2003). Lacrimichnus? isp., as described by Jagt (2007), is a rounded groove, probably a gastropod homing scar (compare Santos et al. 2003, 2004); this lacks the complexity of $S$. collinsi igen. et isp. nov. Finally, Oichnus halo Neumann \& Wisshak, 2009, now transferred to the ichnogenus Loxolenichnus Breton, Wisshak, Néraudeau \& Morel, 2017 (see Wisshak et al. 2019 , p. 24) and recorded from a test of the echinoid genus Echinocorys, differs in having in faint additional ring and in lacking a central depression (Jagt \& Deckers 2014).

Occurrence. - Known only from the type locality at the former Ankerpoort-Curfs quarry, southern Limburg, the Netherlands (Fig. 1); uppermost Meerssen Member 
(subunit IVf-6), Maastricht Formation, uppermost Maastrichtian (Upper Cretaceous).

\section{Salsariichnus collinsi igen. et isp. nov.}

Types. - Holotype, NHMM PK M2634-1, specimen at top of Fig. 3E. Paratypes, all other specimens on NHMM PK M2634-1 as well as all examples on NHMM PK M3093 and NHMM PK M3094. Specimens are preserved on external moulds of gastropods; the substrate is a mediumto coarse-grained biocalcarenite that does not favour definition of fine details.

Type horizon and locality. - Former Ankerpoort-Curfs quarry, near Geulhem, southern Limburg, the Netherlands (Fig. 1); uppermost Meerssen Member (subunit IVf-6), Maastricht Formation, of latest Maastrichtian (Late Cretaceous) age.

Etymology. - In memory of our late colleague, Mr. J.S.H. Collins (1927-2019), a noted expert on fossil barnacles and decapod crustaceans.

Diagnosis. - As for the ichnogenus.

Description. - Pits on external moulds are all clustered and arrayed as a column along the long axes of highturreted gastropod shells (Figs 2A-C, 3A-C). Pits are broad, dish-like depressions, with a rounded to polygonal outline where they are closely packed. Within this dish is a circular, shallow, sunken groove, of variable section, but commonly semi-circular. The central raised area is rounded in outline, domed; in turn, this dome has a central, rounded depression. Pits are commonly rounded, but closely packed, either in lateral contact or leaving only a small gap between pits, commonly resulting in a more polygonal outline.

Figure 2. The trace fossil Salsariichnus collinsi igen. nov., isp. nov., infesting campanilid (A, C, D) and aporrhaid (B) gastropods from the former Ankerpoort-Curfs quarry, southern Limburg, the Netherlands; uppermost Meerssen Member (subunit IVf-6), Maastricht Formation, latest Maastrichtian [zone of the belemnitellids, Belemnella (Neobelemnella) kazimiroviensis and $B$. (N.) skolozdrownae]. All three are natural external moulds; the accompanying internal moulds could not be recognised after blasting when the quarry was still in operation. All trace fossils are paratypes unless stated otherwise. - A, D - NHMM PK M2634-1, in 'Cerithium' tuberculiferum Binkhorst van den Binkhorst, 1861; A - note that pits are densely packed on the right in the top half of the specimen, but over the full width of the shell near the bottom; holotype in the centre, just above mid-height (compare with Fig. 3C, E); D - detail of pits in lower half of gastropod mould. • B - NHMM PK M3093, in Alaria binkhorsti Ubaghs, 1879; pits are clustered more or less in a row in the top half of the shell. • C - NHMM PK M3094, in 'Cerithium' tuberculiferum; pits forming a broad, densely packed band in the centre of the specimen. Specimens uncoated. All scale bars equal $10 \mathrm{~mm}$.
Remarks. - These traces represent most likely the attachment scars of a gregarious, sessile organism rather than the homing scars of vagile benthos. The close-packed nature of these scars has modified the rounded outlines into polygonal shapes. A vagile organism would only be able to adapt to this if either it could easily change the outline of its shell to fit or it lacked a hard shell. The former seems rather draconian, necessitating a constant race to adjust its shape to fit a changing outline as neighbouring shells grew, encroaching on its space. The latter seems unlikely, homing scars being the mark of cap-like gastropods such as limpets, hipponicids and platyceratids (Vermeij 1998; Bromley 2004, p. 463; Donovan \& Webster 2013).

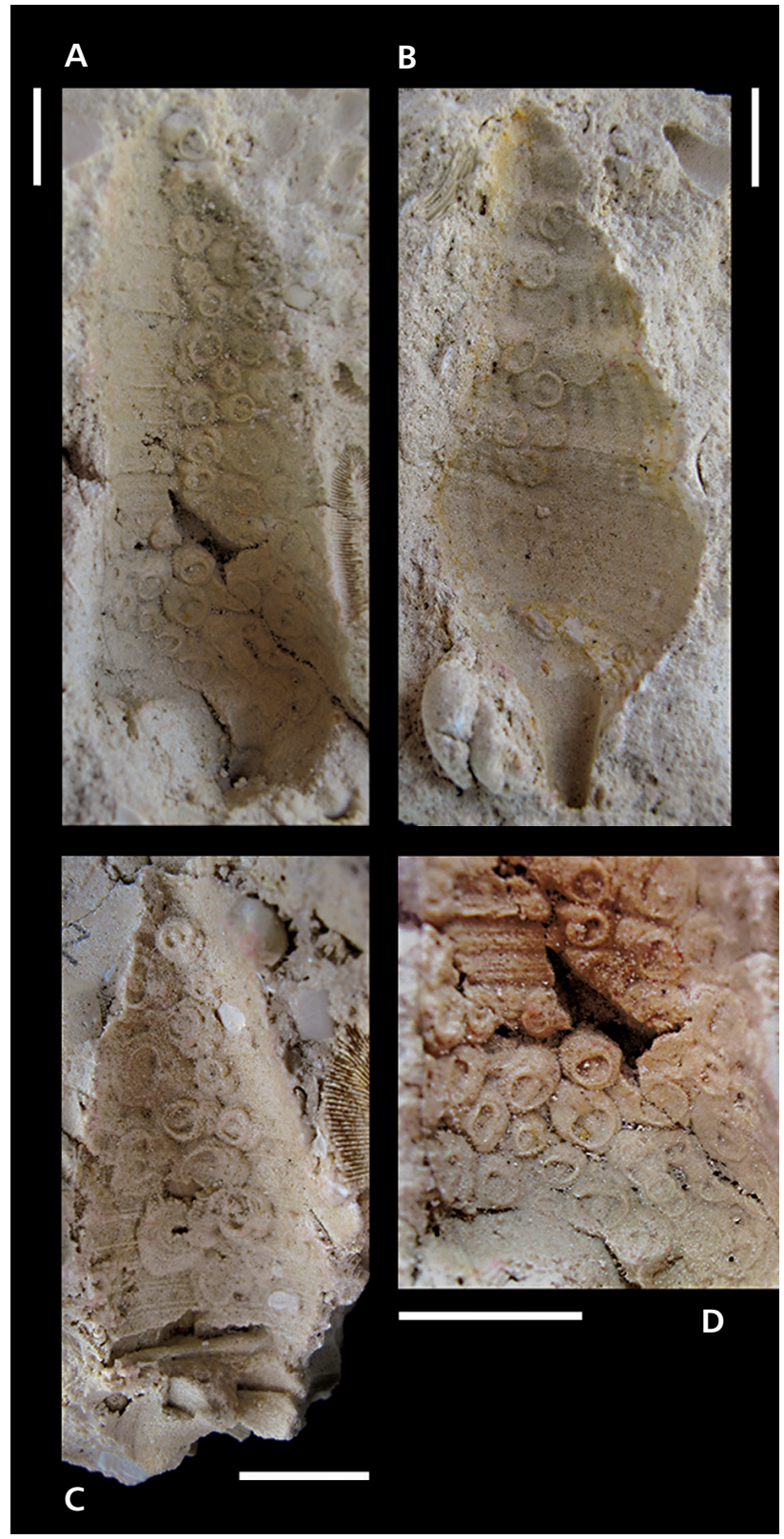




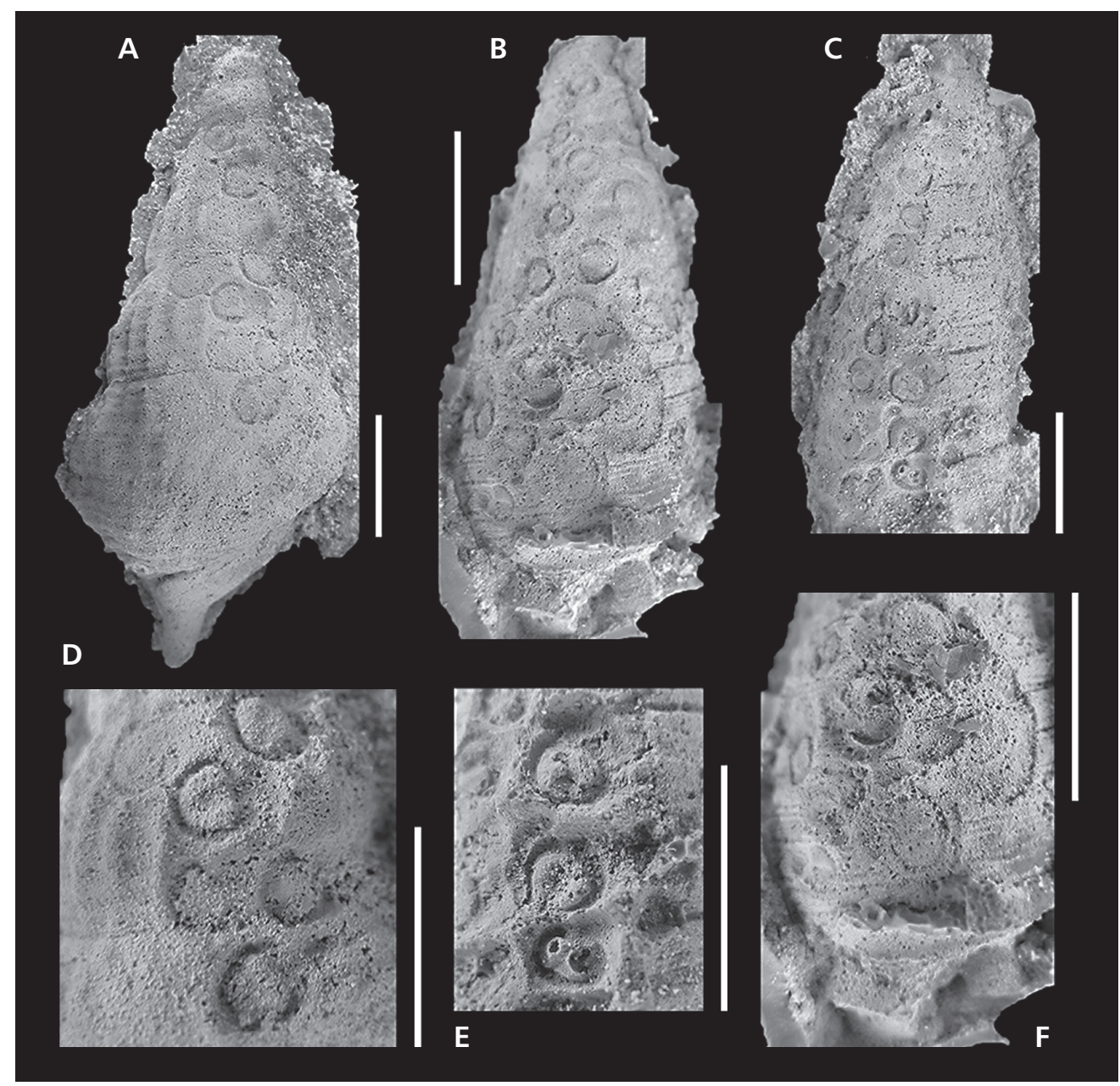

Figure 3. The trace fossil, Salsariichnus collinsi igen. nov., isp. nov., infesting campanilid (B, C, E, F) and aporrhaid (A, D) gastropods from the former Ankerpoort-Curfs quarry, southern Limburg, the Netherlands; uppermost Meerssen Member (subunit IVf-6), Maastricht Formation, latest Maastrichtian (see Fig. 2). Latex casts. All trace fossils are paratypes unless stated otherwise. • A, D - NHMM PK M3093 in Alaria binkhorsti; A - clustering of pits on the shell; D - details of several pits. • B, F - NHMM PK M3094 in 'Cerithium' tuberculiferum; B - shell with numerous pits; F - pits in the lower half of the shell. • C, E - NHMM PK M2634-1 in 'Cerithium' tuberculiferum; C - upper part of the shell, pitted on the left; holotype just below the centre; $\mathrm{E}$ - detail of the linear array of pits; holotype at the top. Specimens coated with ammonium chloride prior to photography. All scale bars equal $10 \mathrm{~mm}$.

\section{Discussion}

These scars were produced by a gregarious, sessile invertebrate. The specimens are all about the same size on any given shelly substrate, suggesting that each represents a single spatfall. These criteria immediately suggest that $S$. collinsi igen. nov., isp. nov. was the spoor of a barnacle or barnacle-like organism. The earliest balanomorphs were of Late Cretaceous age (Newman et al. 1969, p. R283; Gale \& Sørensen 2014), so it is at least possible. However, to date only asymmetrical verrucomorphs have been recorded from the highest levels of the Maastricht Formation (Jagt 2011, Gale 2014). In view of the fact that representatives of either cirripede group have calcareous valves, their shells should be been preserved in situ. Further, S. collinsi igen. nov., isp. nov. differs markedly from the attachment scars and basal plates associated with fossil balanomorph (Miller \& Brown 1979) and verrucomorph (Bromley \& Martinell 1991) barnacles. Thus, our interpretation of the possible producing organism remains speculative.

The recently described etching trace, Solealites ovalis Uchman \& Rattazzi, 2018, in lithic clasts from the Oligocene Savignone Conglomerate in northwest Italy, is superficially similar. This taxon comprises shallow, oval depressions with a flat, central elevation for which limpet gastropods (Patellogastropoda; homing scars), other snails or sea anemones have been suggested as possible producer. These lack the complexity of the present trace in gastropod shells (compare Bromley \& Heinberg 2006, fig. 4). Finally, Spirolites radwanskii Uchman, Stachacz \& Salamon, 2018, a depression in the form of an involute, smooth or annulated spiral, the width of which increases outwardly, differs in not being circular, dish-like and in 
lacking the central rounded dome with a central depression of $S$. collinsi.

It has been assumed in the above discussions that infestation of the pit-former of S. collinsi was after the death of the gastropod. This seems most likely as the distinctive features of infestation are mainly linear associations of the new trace which occur along almost the entire extent of the shell in two of the three specimens (Figs $2 \mathrm{~A}-\mathrm{C}, 3 \mathrm{~A}-\mathrm{C}$ ). This suggests that the shells were recumbent on the sea floor (post-mortem) rather than upright (pre-mortem). Attachment pre-mortem would most likely be towards the apex of the shell, raising the sessile producers of $S$. collinsi above the substrate and into clean water for feeding on plankton, the common sustenance of sessile zoobenthos, and distancing the infesters from the snail's radula. In contrast, a dead gastropod lying on the seafloor would provide only limited elevation along its whole length, suggesting the distribution of the new trace on these shells may have been on recumbent (dead) specimens.

\section{Acknowledgements}

We thank the former proprietors of the Ankerpoort-Curfs quarry for permitting access to their grounds for collecting and the journal reviewers, Olev Vinn and Jiří Žitt, for pertinent comments on an earlier version of the typescript.

\section{References}

Belaústegui, Z., Gibert, J.M. De, Nebelsick, J.H., Domėnech, R. \& Martinell, J. 2013. Clypeasteroid echinoid tests as benthic islands for gastrochaenid bivalve colonization: evidence from the Middle Miocene of Tarragona, north-east Spain. Palaeontology 56, 783-796. DOI 10.1111/pala.12015

Binkhorst van den Binkhorst, J.-T. van, 1861-1862. Monographie des gastéropodes et des céphalopodes de la Craie supérieure du Limbourg, suivie d'une description de quelques espèces de crustacés du même dépôt crétacé, avec dix-huit planches dessinées et lithographiées par C. Hohe, de Bonn, vi $+83+44$ pp. A. Muquardt, Bruxelles/J. Muller Frères, Maastricht.

Blissett, D.J. \& Pickerill, R.K. 2003. Oichnus excavatus Donovan and Jagt, 2002 from the Moneague Formation, White Limestone Group, of Jamaica. Caribbean Journal of Science 39, 221-223.

Breton, G., Wisshak, M., Néraudeau, D. \& Morel, N. 2017. Parasitic gastropod bioerosion trace fossil on Cenomanian oysters from Le Mans, France and its ichnologic and taphonomic context. Acta Palaeontologica Polonica 62, 45-57. DOI 10.4202/app.00304.2016

Bromley, R.G. 1981. Concepts in ichnotaxonomy illustrated by small round holes in shells. Acta Geológica Hispánica 16, $55-64$.
BRomLEy, R.G. 2004. Astratigraphy ofmarinebioerosion, 455-479. In McIlroy, D. (ed.) The application of ichnology to palaeoenvironmental and stratigraphic analysis. Geological Society London, Special Publication 228.

DOI 10.1144/GSL.SP.2004.228.01.20

Bromley, R.G. \& Heinberg, C. 2006. Attachment strategies of organisms on hard substratrs: a palaeontological view. Palaeogeography, Palaeoclimatology, Palaeoecology 232, 429-453. DOI 10.1016/j.palaeo.2005.07.007

Bromley, R.G. \& Martinell, J. 1991. Centrichnus, new ichnogenus for centrically patterned attachment scars on skeletal substrates. Bulletin of the Geological Society of Denmark 38, 243-252.

Brown, L. (ed.) 1993. The New Shorter Oxford English Dictionary on Historical Principles. Two volumes, xxv+3801 pp. Oxford University Press, Oxford.

Donovan, S.K. \& JAGT, J.W.M. 2002. Oichnus Bromley borings in the irregular echinoid Hemipneustes Agassiz from the type Maastrichtian (Upper Cretaceous, The Netherlands and Belgium). Ichnos 9, 67-74.

DOI 10.1080/10420940216411

Donovan, S.K. \& JAGT, J.W.M. 2013. Site selectivity of the pit Oichnus excavatus Donovan and Jagt infesting Hemipneustes striatoradiatus (Leske) (Echinoidea) in the Type Maastrichtian (Upper Cretaceous, The Netherlands). Ichnos 20, 112-115. DOI 10.1080/10420940.2013.815616

Donovan, S.K. \& JAGT, J.W.M. (in press). Oichnus simplex Bromley infesting Hemipneustes striatoradiatus (Leske) (Echinoidea) from the Maastrichtian type area (Upper Cretaceous, the Netherlands). Ichnos, 1-6. DOI 10.1080/10420940.2019.1584561

Donovan, S.K. \& Webster, G.D. 2013. Platyceratid gastropod infestations of Neoplatycrinus Wanner (Crinoidea) from the Permian of West Timor: speculations on thecal modifications. Proceedings of the Geologists' Association 124, 988-993. DOI 10.1016/j.pgeola.2013.01.004

Donovan, S.K., Jagt, J.W.M. \& Langeveld, M. 2018. A dense infestation of round pits in the irregular echinoid Hemipneustes striatoradiatus (Leske) from the Maastrichtian of the Netherlands. Ichnos 24, 25-29. DOI 10.1080/10420940.2017.1345736

Felder, W.M. \& Bosch, P.W. 2000. Geologie van Nederland, deel 5. Krijt van Zuid-Limburg. 192 pp. Nederlands Instituut voor Toegepaste Geowetenschappen TNO, Delft/ Utrecht.

Gale, A.S. 2014. Origin and phylogeny of verrucomorph barnacles (Crustacea, Cirripedia, Thoracica). Journal of Systematic Palaeontology 13, 753-789.

DOI 10.1080/14772019.2014.954409

Gale, A.S. \& Sørensen, A. 2014. Origin of the balanomorph barnacles (Crustacea, Cirripedia, Thoracica): new evidence from the Late Cretaceous (Campanian) of Sweden. Journal of Systematic Palaeontology 13, 791-824. DOI 10.1080/14772019.2014.954824

Gould, S.J. 1980. Nature's odd couples, 278-288. In Gould, S.J. The Panda's Thumb. W.W. Norton, New York.

Herngreen, G.F.W. \& Wong, T.E. 2007. Cretaceous, 127-150. 
In Wong, T.E., BAtJes, D.A.J. \& JAGER, J. DE (eds) Geology of the Netherlands. Royal Netherlands Academy of Arts and Sciences, Amsterdam.

JAGT, J.W.M. 2007. A Late Cretaceous gastropod homing scar (possibly ichnogenus Lacrimichnus) from southern Limburg, The Netherlands. Scripta Geologica 134, 19-25.

JAGT, J.W.M. 2011. Charles Darwin and Joseph de Bosquet brothers in barnacles: how diminutive crustaceans helped shape a theory, 597-605. In HART, M. (ed.) Proceedings of the $8^{\text {th }}$ International Symposium on the Cretaceous System, Plymouth, 6-12 September 2009. Cretaceous Research 32. DOI 10.1016/j.cretres.2011.03.008

JAGT, J.W.M. \& Deckers, M.J.M. 2014. Opmerkelijke LuiksLimburgse Krijtfossielen. Deel 22. Het sporenfossiel Oichnus halo. Natuurhistorisch Maandblad 103, 248-250.

JAGT, J.W.M. \& JAGT-YAZYKova, E.A. 2012. Stratigraphy of the type Maastrichtian - a synthesis, 5-32. In JAGT, J.W.M., Donovan, S.K. \& Jagt-Yazykova, E.A. (eds) Fossils of the type Maastrichtian (Part 1). Scripta Geologica Special Issue 8.

Jagt, J.W.M., Van Bakel, B.W.M., Cremers, G., Deckers, M.J.M., Dortangs, R.W., Van Es, M., Fraaije, R.H.B., Kisters, P.J.M., Van Knippenberg, P.H.M., Lemmens, H., Nieuwenhuis, E., Severijns, J. \& Stroucken, J.W. 2013. Het Vroeg Paleoceen (Danien) van zuidelijk Limburg en aangrenzend gebied - nieuwe fauna's en nieuwe inzichten. Afzettingen WTKG 34, 198-230.

Kaunhowen, F. 1898. Die Gastropoden der Maestrichter Kreide. Paläontologische Abhandlungen, Neue Folge 4, 1-132.

Keutgen, N. 2018. A bioclast-based astronomical timescale for the Maastrichtian in the type area (southeast Netherlands, northeast Belgium) and stratigraphic implications: the legacy of P.J. Felder. Netherlands Journal of Geosciences 97, 229-260. DOI 10.1017/njg.2018.15

Keutgen, N., Remin, Z. \& JAGt, J.W.M. 2017. The late Maastrichtian Belemnella kazimiroviensis group (Cephalopoda, Coleoidea) in the Middle Vistula valley (Poland) and the Maastricht area (the Netherlands, Belgium) - taxonomy and palaeobiological implications. Palaeontologia Electronica 20.2.38A, 1-29. DOI 10.26879/671

Kongiel, R. 1962. On belemnites from Maastrichtian, Campanian and Santonian sediments in the Middle Vistula Valley (central Poland). Prace Muzeum Ziemi 5, 3-140.

Leske, N.G. 1778. Iacobi Theodori Klein naturalis dispositio echinodermatum, edita et descriptionibus novisque inventis et synonymis auctorum et aucta a N. G. Leske. xxii +278 pp. G.E. Beer, Lipsiae (Leipzig).

Miller, W. III \& Brown, N.A. 1979. The attachment scars of fossil balanids. Journal of Paleontology 53, 208-210.

Neumann, C. \& Wisshak, M. 2009. Gastropod parasitism on Late Cretaceous to early Paleocene holasteroid echinoids - evidence from Oichnus halo isp. n. Palaeogeography, Palaeoclimatology, Palaeoecology 284, 115-119.

DOI 10.1016/j.palaeo.2009.09.010

Newman, W.A., Zullo, V.A. \& Withers, T.H. 1969. Cirripedia, R206-R295. In Moore, R.C. \& Teichert, C. (eds) Treatise on Invertebrate Paleontology, Part R, Arthropoda 4(1). Geological Society of America and University of Kansas, Boulder \& Lawrence. DOI 10.17161/dt.v0i0.5628

Pickerill, R.K. \& Donovan, S.K. 1997. Ichnology and biotic interactions on a Pleistocene gastropod from southeast Jamaica. Journal of the Geological Society of Jamaica 32, 19-24.

Santos, A., Mayoral, E. \& Muñiz, F. 2003. New trace fossils produced by etching molluscs from the Upper Neogene of the southwestern Iberian Peninsula. Acta Geologica Polonica 53, 181-188, pls 1, 2.

Santos, A., Mayoral, E. \& MuñIz, F. 2004. Additional note to new trace fossils produced by etching molluscs from the Upper Neogene of the southwestern Iberian Peninsula. Acta Geologica Polonica 54, 53-54.

SKoŁozdrównA, Z. 1932. Znaczenie alveoli i szczeliny alveolarnej dla systemattyki rodzaju Belemnitella [sic]. Posiedzenia Naukowe, Państwowego Instytutu Geologicznego 33, 117.

TApanila, L. \& EbBestad, J.O.R. 2008. Benthic island community on the back of a snail: Silurian, Anticosti Island, Canada. Canadian Journal of Earth Sciences 45, 203-211. DOI 10.1139/E07-054

TAYlor, P.D. \& Wilson, M.A. 2002. A new terminology for marine organisms inhabiting hard substrates. Palaios 17, 522-525.

DOI 10.1669/0883-1351(2002)017<0522:ANTFMO >2.0.CO;2

UBAGHS, J.C. 1879. Description géologique et paléontologique du sol du Limbourg avec Catalogue general des fossiles du terrain crétacé, Coupe de la superposition des couches, et Description de quelques grands vertébrés de la craie supérieure de Maastricht. 275 + ii pp. J.J. Romen et fils, Ruremonde (Roermond).

Uchman, A. \& Rattazzi, B. 2018. A new etching trace from the Savignone Conglomerate (Oligocene), NW Italy, probably produced by limpet gastropods. Acta Geologica Polonica 68, 651-662.

Uchman, A., Stachacz, M. \& Salamon, K. 2018. Spirolites radwanskii n. igen., n. isp.: vermetid gastropod attachment etching trace fossil from middle Miocene rocky coast of the Paratethys, Poland. Journal of Paleontology 92(5), 883-895. DOI 10.1017/jpa.2017.95

Vermeit, G.J. 1998. Sabia on shells: a specialized Pacific-type commensalism in the Caribbean Neogene. Journal of Paleontology 72, 465-472. DOI 10.1017/S0022336000024215

Wisshak, M., Knaust, D. \& Bertling, M. 2019. Bioerosion ichnotaxa: review and annotated list. Facies 65, 24.

DOI 10.1007/s10347-019-0561-8 